\title{
Physicochemical Properties, Mineral Content, Antioxidant Activities, and Microbiological Quality of Bupleurum spinosum Gouan Honey from the Middle Atlas in Morocco
}

\author{
Hassan Laaroussi, Toufik Bouddine $\mathbb{D}$, Meryem Bakour, Driss Ousaaid $(\mathbb{D}$, \\ and Badiaa Lyoussi $\mathbb{B}$ \\ Laboratory of Physiology Pharmacology and Environmental Health, Department of Biology, Faculty of Sciences Dhar Mehraz, \\ University Sidi Mohamed Ben Abdellah, 30000 Fez, Morocco \\ Correspondence should be addressed to Badiaa Lyoussi; lyoussi@gmail.com
}

Received 16 July 2019; Revised 5 December 2019; Accepted 26 December 2019; Published 22 January 2020

Academic Editor: Susana Fiszman

Copyright (C) 2020 Hassan Laaroussi et al. This is an open access article distributed under the Creative Commons Attribution License, which permits unrestricted use, distribution, and reproduction in any medium, provided the original work is properly cited.

\begin{abstract}
Monofloral honeys (Bupleurum Spinosum) collected from different geographical locations of Moroccan Middle Atlas were evaluated for various potential attributes. For physicochemical parameters, the results showed the following values: $\mathrm{pH}$ (4.02-4.81); free acidity $(12.16-31.85 \mathrm{mEq} / \mathrm{kg}) ;$ lactonic acidity $(4.98-14.14 \mathrm{mEq} / \mathrm{kg})$; total acidity $(18.37-45.53 \mathrm{mEq} / \mathrm{kg}) ; \mathrm{moisture}$ (15.81-19.20\%); ash (0.21-0.55); electrical conductivity (427.38-682.16 mS/cm); diastasic activity (10.76-26.01); TSS (80.40-84.20\%); melanoidins (0.21-1.15), and Pfund scale (30.47-175.53 mm). Potassium was the most important mineral among the tent evaluated elements, followed by sodium and calcium. All tested samples have high antioxidant activities and correlate with phenols, flavonoids, and ascorbic acid content. In regards to safety (sulfite-reducing clostridia and Salmonella spp.) and sanitary quality (faecal coliforms), all honey samples were negative. In addition, low counts of yeast and molds were detected, and the values of total aerobic mesophilic bacteria and Bacillus Sp. confirm the good quality of honey. The outcome of this study showed that all samples have good physicochemical properties, high antioxidant activities, and acceptable microbiological state, respecting the quality control criteria set by the international norms.
\end{abstract}

\section{Introduction}

The use of honey by humanity goes back to the most remote times of its history [1]. It is a sweet substance produced by bees on mixing nectar of flowers with its hypopharyngeal excretions [2]. Honey is usually composed of $38 \%$ fructose, $31 \%$ glucose, $17 \%$ water, $7 \%$ maltose, $1.3 \%$ other sugars, and $3.5 \%$ various constituents such as minerals, vitamins, enzymes, proteins, phenolic compounds, organic acids, and pigments [3], and the composition of honey is influenced by many factors including the nature of soil, weather conditions, butined floral source, and harvest period [4].

Honey has various pharmacologic properties such as wound healing, antimicrobial activity, anti-inflammatory, antidiabetic, antioxidant, and anti-tumoral effects. The analysis of bioactive compounds in honey showed the presence of vitamins (E, A, K, B1, B2, B6, C), phenolics, flavonoids, amino acids, and fatty acids [5].

Morocco has a floristic nature of vast diversity. Beekeeping is the most benefited from the wealth of Moroccan flora, with a main annual production estimate between 2500 and 3500 tons of honey [6]. The evaluation of honey quality is a crucial step to guarantee the safety of the consumers, notably to evaluate the good practice of beekeepers in order to draw up relevant strategies focused on the quality of production and standards establishing [7].

In order to understand the influence of geographical conditions on the composition and quality of Moroccan monofloral honey, the main objective of this study was to determine the antioxidant capacity, the mineral content, the 
physicochemical characterization, and microbiological quality of eight samples of Bupleurum spinosum honey, harvested from different Middle Atlas areas in Morocco. It is expected that the results of this study will contribute to the definition of quality standards of honey in Morocco.

\section{Materials and Methods}

2.1. Honey Samples. Eight monofloral honeys (Bupleurum Spinosum Gouan) (500 g for each sample) were harvested in summer from hives free from any pathogens, disease, mite, and pesticide spray. The hives were installed in different geographical locations of Middle Atlas in Morocco: Enjil, ElMers, Boulemane, Bouyablane, Tafajight, Ait-Bazza, Timahdite, and Ribat El-Kheire (Table 1) and (Figure 1). The bee breed that exists in these areas was Apis mellifera intermissa, and it was placed with their queens. The major vegetations in these regions were Bupleurum spinosum, Peganum harmala, Achillea odorata, Carlina lanata, Dittrichia viscosa, Prunus dulcis, Anthyllis cytisoides, Origanum vulgare, Rosmarinus officinalis, Cytisus arboreus, Medicago sativa, Ceratonia siliqua, Mentha pulegium, Globularia alypum, Thymus vulgaris, Thymus zygis, Marrubium vulgare, and Lavendula officinalis.

2.2. Melissopalynological Analysis. The pollen spectrum in the studied honey samples was determined according to the work of Louveaux et al. [8]. Pollen is concentrated by centrifuging $2 \mathrm{~g}$ of honey dissolved in $10 \mathrm{ml}$ of distilled water, examining the sediment, and evaluating it under a microscope. A minimum of 1000 different pollen grains were counted for each honey sample, and the analysis was performed twice. According to Louveaux et al. [8], the following terms are used for frequency classes: pollen content was classified as predominant pollen (if represents more than $45 \%$ of the pollen grains counted), secondary pollen (if represents an amount between $16 \%$ and $45 \%$ of the pollen grains counted), important minor pollen (if represents an amount between $3 \%$ and $15 \%$ of the pollen grains counted), and minor pollen (if represents an amount less than $3 \%$ of the pollen grains counted).

2.3. Physicochemical Analysis. Electrical conductivity was measured using an electrical conductivity cell of a solution of $20 \mathrm{~g}$ dry matter of honey in $100 \mathrm{ml}$ distilled water, and $\mathrm{pH}$ was measured using a $\mathrm{pH}$ meter $(10 \mathrm{~g}$ of honey in $100 \mathrm{ml}$ of ultrapure water). The free acidity was obtained by titration of a solution of honey ( $1 \mathrm{~g}$ in $25 \mathrm{ml}$ of ultrapure water) with a solution of sodium hydroxide $0.05 \mathrm{M}$ up to the equivalence point $\mathrm{pHe}=8.3$. Lactone acidity was obtained by adding $1 \mathrm{ml}$ of the $0.05 \mathrm{M}$ sodium hydroxide solution, followed by titration with $0.05 \mathrm{M}$ hydrochloric acid solution to return to the equivalence point. Ash content was determined after a preliminary ashing of honey sample at a temperature not exceeding $600^{\circ} \mathrm{C}$, the weight of ash was measured, water content and total soluble solids were measured using a refractometer, and diastase activity was determined as follows: $2 \mathrm{ml}$ of honey extract $(1 \mathrm{~g}$ of honey in $1.5 \mathrm{ml}$ of distilled water, $500 \mu \mathrm{l}$ of acetate buffer pH 5.3, and $300 \mu \mathrm{l}$ of sodium chloride and then finish line $5 \mathrm{ml}$ with distilled water) and $2 \mathrm{ml}$ of starch solution (add $2 \mathrm{~g}$ of starch in $90 \mathrm{ml}$ of distilled water, boil for $3 \mathrm{~min}$, and terminate in the $100 \mathrm{ml}$ line with water) were put in the bath at $40^{\circ} \mathrm{C}$. After $15 \mathrm{~min}, 1 \mathrm{ml}$ of the starch solution was added to that of the extract and the timer started. After 2 minutes, $100 \mu \mathrm{l}$ of the mixture was taken and added to $1 \mathrm{ml}$ of the iodine solution (add $4 \mathrm{~g}$ of iodine potassium to $400 \mu \mathrm{l}$ of iodine stock and fill up to $100 \mathrm{ml}$ with distilled water) and $4 \mathrm{ml}$ of distilled water. Absorbance was read at $660 \mathrm{~nm}$. For the negative control, the starch solution was added to $2 \mathrm{ml}$ of distilled water. The activity of the diastase was calculated according to the following formula:

$$
\text { Diastase Number }=\frac{300}{\mathrm{Tx}} \text {. }
$$

where Tx: the time it took the reaction for the absorbance of the blue color to decrease to approximately 0.235 [9]. Color was determined with a spectrophotometer by measuring the absorbance of honey solutions at $635 \mathrm{~nm}$ ( $10 \mathrm{~g}$ of honey in $20 \mathrm{~mL}$ of distilled water) [10]. The $\mathrm{mm}$ Pfund values were obtained using the following formula:

$$
\text { mm Pfund }=-38.7+371.39 \times \text { Absorbance. }
$$

Melanoidins content was estimated based on the browning index by measuring the net absorbance of the honey samples at $450 \mathrm{~nm}$ and $720 \mathrm{~nm}$, and the net absorbance was calculated at A450-A720 [11].

2.4. Determination of Mineral Elements. Mineral elements were obtained by the calcination method using ICP-AES. Briefly, $5 \mathrm{~mL}$ of nitric acid $0.1 \mathrm{M}$ was added to the ashes, and the mixture was stirred on a heating plate until the total evaporation of nitric acid. Then, $10 \mathrm{~mL}$ of the same acid was added and the mixture was made up to $25 \mathrm{~mL}$ with ultrapure water, mineral elements were determined using an air/ acetylene flame, and the quantitative determination was carried out after calibrating the instrument using ranges of calibrations of $\mathrm{Na}, \mathrm{K}, \mathrm{Ca}, \mathrm{Mg}, \mathrm{Fe}, \mathrm{Cu}, \mathrm{Zn}, \mathrm{Ni}, \mathrm{Cd}$, and $\mathrm{Pb}$ dissolved in $0.1 \%$ lanthanum. All samples were analyzed in triplicate [12].

\subsection{Bioactive Compounds and Antioxidant Activities}

2.5.1. Total Phenolic Content. The method of Folin-Ciocalteau described by Bakour et al. [13] was used for the polyphenol quantification, and $5 \mathrm{~g}$ of honey was mixed with $10 \mathrm{~mL}$ of distilled water. One hundred microliters of this solution was mixed with $500 \mu \mathrm{L}$ of Folin-Ciocalteau $(0.2 \mathrm{~N})$ reagent and $400 \mu \mathrm{L}$ of sodium carbonate solution. Gallic acid was used as a standard to achieve the calibration curve, and the result was expressed in mg gallic acid equivalent per $100 \mathrm{~g}$ sample (mg GA/100 g).

2.5.2. Total Flavonoids Content. The method described by Bakour et al. [13] was followed for the determination of the flavonoids contents, and $5 \mathrm{~g}$ of honey were mixed with $10 \mathrm{~mL}$ 
TABLE 1: Geographical locations of honey samples studied.

\begin{tabular}{|c|c|c|c|c|c|c|}
\hline Samples & Locality name & Latitude & Longitude & Altitude (m) & Pluviometry and temperature & Harvest year \\
\hline $\mathrm{H} 1$ & Bouyablane & $33^{\circ} 39^{\prime} 52.4^{\prime \prime} \mathrm{N}$ & $4^{\circ} 05^{\prime} 26.2^{\prime \prime} \mathrm{W}$ & 2078 & $4.3-80.6 \mathrm{~mm} 9.8$ to $28.2^{\circ} \mathrm{C}$ & 2015 \\
\hline $\mathrm{H} 2$ & El-Mers & $33^{\circ} 26^{\prime} 41.2^{\prime \prime} \mathrm{N}$ & $4^{\circ} 26^{\prime} 51.0^{\prime \prime} \mathrm{W}$ & 1406 & $8-45 \mathrm{~mm} 4.5$ to $23.1^{\circ} \mathrm{C}$ & 2016 \\
\hline H3 & Boulemane & $33^{\circ} 21^{\prime} 46.3^{\prime \prime} \mathrm{N}$ & $4^{\circ} 43^{\prime} 48.3^{\prime \prime} \mathrm{W}$ & 1752 & $9-60 \mathrm{~mm} 3.2$ to $22.1^{\circ} \mathrm{C}$ & 2016 \\
\hline $\mathrm{H} 4$ & Ribat El-Kheire & $33^{\circ} 49^{\prime} 24.5^{\prime \prime} \mathrm{N}$ & $4^{\circ} 24^{\prime} 47.8^{\prime \prime} \mathrm{W}$ & 1077 & $3-100.4 \mathrm{~mm} 4$ to $35^{\circ} \mathrm{C}$ & 2016 \\
\hline H5 & Tafajight & $33^{\circ} 34^{\prime} 08.7^{\prime \prime} \mathrm{N}$ & $4^{\circ} 17^{\prime} 45.9^{\prime \prime} \mathrm{W}$ & 1433 & $2.4-62.7 \mathrm{~mm} 9.2$ to $26.3^{\circ} \mathrm{C}$ & 2016 \\
\hline H6 & Ait-Bazza & $33^{\circ} 24^{\prime} 32.9^{\prime \prime} \mathrm{N}$ & $4^{\circ} 18^{\prime} 10.5^{\prime \prime} \mathrm{W}$ & 1471 & $7-42 \mathrm{~mm} 4.8$ to $23.3^{\circ} \mathrm{C}$ & 2015 \\
\hline $\mathrm{H} 7$ & Timahdite & $33^{\circ} 14^{\prime} 13.9^{\prime \prime} \mathrm{N}$ & $5^{\circ} 03^{\prime} 45.4^{\prime \prime} \mathrm{W}$ & 1964 & $9-94 \mathrm{~mm} 2.4$ to $21.7^{\circ} \mathrm{C}$ & 2016 \\
\hline $\mathrm{H} 8$ & Enjil & $33^{\circ} 11^{\prime} 14.7^{\prime \prime} \mathrm{N}$ & $4^{\circ} 33^{\prime} 02.2^{\prime \prime} \mathrm{W}$ & 1712 & $7-30 \mathrm{~mm} 9$ to $31^{\circ} \mathrm{C}$ & 2016 \\
\hline
\end{tabular}

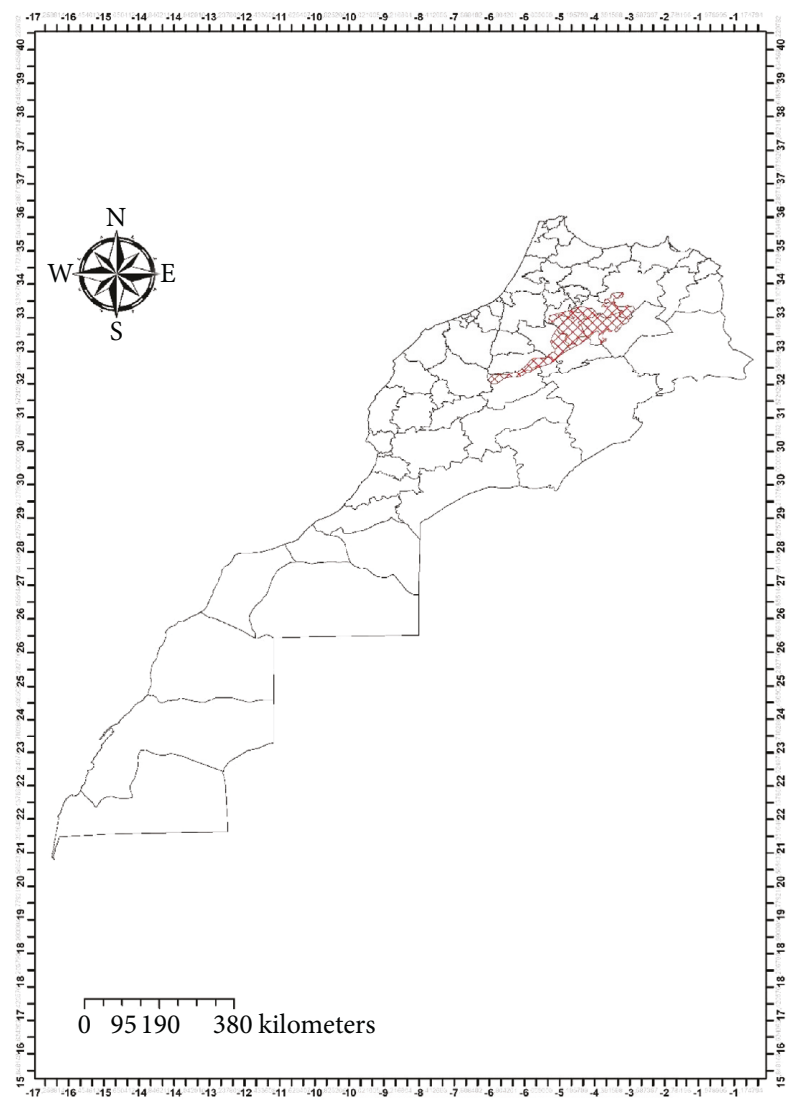

Legend

Middle atlas

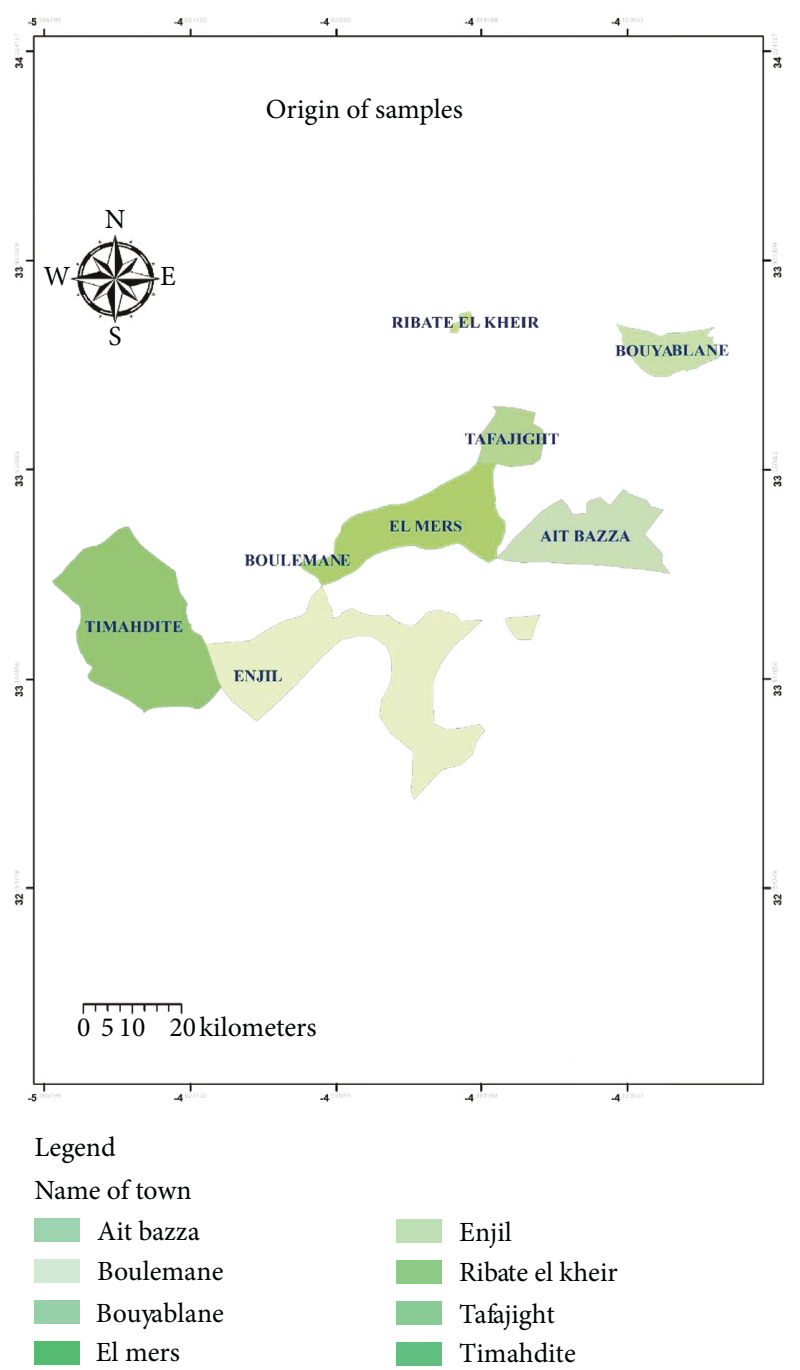

(b)

Figure 1: Map of Morocco showing honey sample regions in the middle Atlas.

of distilled water. One hundred microliters of this solution was mixed with sodium nitrite $(5 \%)$ and $150 \mu \mathrm{L}$ of $\mathrm{Alcl}_{3}$ solution (10\%), $200 \mu \mathrm{L}$ of $\mathrm{NaOH}(1 \%) 1 \mathrm{M}$ was added after $5 \mathrm{~min}$, and absorbance of the reaction mixture was measured at $510 \mathrm{~nm}$. The results obtained were expressed as the milligrams of the quercetin equivalent per 100 gram of the sample (mg QE/100 g).
2.5.3. Ascorbic Acid Content. The method of Nweze et al. was used to quantify the ascorbic acid contents in honey samples [14]; $5 \mathrm{~g}$ of honey was mixed with $10 \mathrm{~mL}$ of distilled water, and the following solution was prepared: $1 \%$ starch indicator solution, vitamin C standard solution $(0.001 \mathrm{~g} / \mathrm{ml}$ of distilled water), and iodine solution (prepared in a $500 \mathrm{ml}$ beaker by mixing $5 \mathrm{~g}$ potassium iodide (KI) and $0.268 \mathrm{~g}$ 
potassium iodate (KIO3) with $200 \mathrm{ml}$ of distilled water; $30 \mathrm{ml}$ of 3 molar sulfuric acid was added into the beaker and diluted with distilled water until $500 \mathrm{ml}$ solution). Standardization of the iodine solution with the vitamin C standard solution was performed by mixing $25 \mathrm{ml}$ of vitamin C solution with 10 drops of $1 \%$ starch solution and then titrated against iodine solution until blue-black color was observed. Titrations were repeated in triplicates. The volume of the honey sample used in the titrations was measured, and the concentration of ascorbic acid in mg per $100 \mathrm{~g}$ of honey was calculated.

2.5.4. Total Antioxidant Capacity. The total antioxidant capacity of honey samples was evaluated by the phosphomolybdenum method according to the method described by Bakour et al. [13], and $5 \mathrm{~g}$ of honey was mixed with $10 \mathrm{~mL}$ of distilled water. Twenty-five microliters of this solution was mixed with $1 \mathrm{~mL}$ of reagent solution $(6 \mathrm{M}$ sulfuric acid, $28 \mathrm{mM}$ sodium phosphate, and $4 \mathrm{mM}$ ammonium molybdate). After 90 min of incubation in a water bath at $95^{\circ} \mathrm{C}$, the absorbance of the solution was measured at $695 \mathrm{~nm}$ against blank. Ascorbic acid was used as the standard calibration. The results were expressed as milligram of ascorbic acid equivalent per gram of the sample.

2.5.5. Free Radical Scavenging Activity. The DPPH radical scavenging activity was measured according to the method described by Miguel et al. [15], and $5 \mathrm{~g}$ of honey was mixed with $10 \mathrm{~mL}$ of distilled water. Twenty-five microliters of this solution was mixed with $875 \mu \mathrm{L}$ of DPPH solution $(63.4 \mu \mathrm{M})$. The absorbance was read at $517 \mathrm{~nm}$, and the antiradical activity was estimated based on the percentage of DPPH radical scavenged using the following formula:

$$
\mathrm{IC}_{50} \%=\left[\frac{(\text { control absorbance }- \text { sample absorbance })}{\text { control absorbance }}\right] \times 100 \text {. }
$$

2.5.6. Microbiological Analysis. In order to examine the microbial contamination in honey samples, the following microorganisms were counted to know the food safety and sanitary quality of honey: fecal coliforms, sulphite-reducing clostridium, yeasts and moulds, aerobic mesophilic bacteria, Salmonella spp., and Bacillus sp. [16]. Honey samples were prepared for testing as follows: $10 \mathrm{~g}$ of each sample was dissolved in $90 \mathrm{ml}$ of sterile distilled water, and then a series of dilutions was carried out with sterile distilled water.

The protocol of ISO 215-2:2008 was followed to count moulds and yeasts in honeys, and the decimal dilutions of each sample of honey were spread on Petri dishes containing Glucose Chloramphenicol Agar-Biolife as a selective medium. Moulds and yeasts were counted after five days from plate incubation at $22-24^{\circ} \mathrm{C}$ [17]. Sulphite-reducing clostridia and fecal coliforms were counted following the protocol of ISO 4831:2006 [18]. For Sulphite-reducing clostridia, the initial suspension and the various decimal dilutions were seeded on Petri dishes containing tryptone sulfite cycloserine (Biolife). The counting was carried out subsequently after incubation of the plates in anaerobiosis at $37^{\circ} \mathrm{C}$ for $20 \mathrm{~h}$. Fecal coliforms were enumerated on Plates containing Violet Red Bile Lactose Agar (VRBLA) after incubation at $44^{\circ} \mathrm{C}$ for $24 \mathrm{~h}$. Salmonella spp. and Bacillus sp. were analyzed and enumerated following the protocol of ISO 6579:2002(E) [19]. For Bacillus sp, the decimal dilution of each honey sample was seeded on Petri dishes containing a solid selective culture medium (MYP Agar). The counting was carried out after incubation of the plates aerobically at $30^{\circ} \mathrm{C}$ for 18 to $48 \mathrm{~h}$, while for Salmonella spp. detection, $25 \mathrm{~g}$ of the honey sample was mixed with $225 \mathrm{~mL}$ of peptone buffered water (Biokar) and incubated at $35^{\circ} \mathrm{C}$ for $24 \mathrm{~h}$. After that, $1 \mathrm{~mL}$ of the incubated mixture was added to a tube containing $10 \mathrm{~mL}$ of tetra-thionate broth. A volume of $0.1 \mathrm{~mL}$ of pre-enrichment has been added to rappaport broth (Biokar), and the tubes were incubated at $37^{\circ} \mathrm{C}$ and $41.5^{\circ} \mathrm{C}$ for $24 \mathrm{~h}$. After this period, a loopful of each selective broth was plated into Petri dishes containing xylose lysine desoxycholate agar. After incubation for $24 \mathrm{~h}$ at $37^{\circ} \mathrm{C}$, present colonies were biochemically tested on TSI agar (Biokar) and API-20E (Biomerieux). Aerobic mesophilic bacteria were counted using the protocol of Lightfoot and Maier [20]. Standard method agar was used for the quantification of aerobic mesophilic bacteria with an incubation period of $48 \mathrm{~h}$ at $35^{\circ} \mathrm{C}$. Briefly, $1 \mathrm{ml}$ of each dilution of honey was incorporated into Standard Plate Count Agar (PCA). Aerobic mesophilic bacteria were counted after incubation of the mixture at $30^{\circ} \mathrm{C}$ for $48 \mathrm{~h}$. Microbial counts were expressed as colony-forming units per gram of honey (cfu.g-1).

2.6. Statistical Analysis. Graphpad prism 5 was used for statistical analysis, comparisons of honey samples were performed by ANOVA followed by the Tukey test, Pearson correlation coefficient $(r)$ at a significance level of $95 \%$ $(p<0.05)$ was used for determinate the correlations between parameters studied, and the principal component analysis (PCA) was accomplished using Past 3.

\section{Results and Discussions}

3.1. Melissopalynological Analysis. Melissopalynological analysis of honey samples (Table 2) showed that B. spinosum was the most abundant pollen in all honey samples, with percentages ranging from $48 \%$ in the honey sample $\mathrm{H} 5$ to $77 \%$ in the honey sample H3. Following Herrero et al., when the percentage of the most abundant pollen was over $45 \%$, the honey was classified as monofloral [21].

3.2. Physicochemical Analysis. Physicochemical analyses are summarized in Table 3 . The recorded $\mathrm{pH}$ of honey samples was ranged between 4.02 and 4.81 , and these values are in the range of Codex Alimentarius Commission Standards [22]. The acid aspect of honey may be due to the presence of aromatic acids, aliphatic acids, and mainly gluconic acid, which is considered as the main organic acid responsible for the acidity of honey $[23,24]$. Its presence in honey is 
TABLE 2: Melissopalynological analysis of eight honey samples.

\begin{tabular}{|c|c|c|c|c|}
\hline Samples & $\begin{array}{l}\text { Predominant } \\
\text { pollen } \\
(>45 \%)\end{array}$ & $\begin{array}{l}\text { Secondary } \\
\text { pollen } \\
(16-45 \%)\end{array}$ & $(3-15 \%)$ & Minor pollen \\
\hline $\mathrm{H} 1$ & $\begin{array}{l}\text { B. spinosum } \\
(63 \%)\end{array}$ & $\begin{array}{c}\text { Asteraceae } \\
(22 \%)\end{array}$ & Rosaceae (11\%) & $\begin{array}{c}\text { Chenopodiaceae, Cistaceae, Rosaceae, Lamiaceae, } \\
\text { Myrthaceae, Salicaceae, Oleaceae, Fabaceae, Asteraceae }\end{array}$ \\
\hline $\mathrm{H} 2$ & $\begin{array}{l}\text { B. spinosum } \\
(67 \%)\end{array}$ & Rutaceae (21\%) & Fabaceae $(7 \%)$ & $\begin{array}{c}\text { Poaceae, Renonculaceae, Asteraceae,Centaureae, Salicaceae, } \\
\text { Cistaceae, Myrthaceae, Plantaginaceae, Rosaceae, } \\
\text { Brassicaceae }\end{array}$ \\
\hline $\mathrm{H} 3$ & $\begin{array}{l}\text { B. spinosum } \\
\text { (77\%) }\end{array}$ & - & Rosaceae (11\%) & $\begin{array}{l}\text { Myrthaceae, Plantaginaceae, Salicaceae, Fabaceae, Cistaceae, } \\
\text { Asteraceae, Rosaceae, Lamiaceae, Rhamnaceae, Brassicaceae }\end{array}$ \\
\hline $\mathrm{H} 4$ & $\begin{array}{l}\text { B. spinosum } \\
(61 \%)\end{array}$ & - & $\begin{array}{c}\text { Lamiaceae }(9 \%) \text { Cistaceae } \\
\text { (8\%) Oleaceae }(11 \%) \\
\text { Apiaceae }(6 \%)\end{array}$ & $\begin{array}{c}\text { Malvaceae, Fabaceae, Asteraceae, Plantaginaceae, Rosaceae, } \\
\text { Campanulaceae, Brassicaceae, Fabaceae, Rosaceae }\end{array}$ \\
\hline H5 & $\begin{array}{l}\text { B. spinosum } \\
(48 \%)\end{array}$ & $\begin{array}{l}\text { Salicaceae } \\
\quad(16 \%)\end{array}$ & $\begin{array}{c}\text { Fabaceae }(15 \%) \text {, Lamiaceae } \\
(10 \%)\end{array}$ & $\begin{array}{c}\text { Campanulaceae, Myrthaceae, Asteraceae, Poaceae, Rosaceae, } \\
\text { Fabaceae, Brassicaceae, Rhamnaceae, Grossulariaceae, } \\
\text { Oleaceae, Cistaceae }\end{array}$ \\
\hline H6 & $\begin{array}{l}\text { B. spinosum } \\
(73 \%)\end{array}$ & $\begin{array}{l}\text { Lamiaceae } \\
\quad(19 \%)\end{array}$ & Rosaceae (5\%) & $\begin{array}{c}\text { Chenopodiaceae, Cistaceae, Renonculaceae, Apiaceae, } \\
\text { Asteraceae, Brassicaceae, Plantaginaceae, Rosaceae, Fabaceae, } \\
\text { Rhamnaceae }\end{array}$ \\
\hline $\mathrm{H} 7$ & $\begin{array}{l}\text { B. spinosum } \\
(55 \%)\end{array}$ & $\begin{array}{l}\text { Rhamnaceae } \\
\qquad(40 \%)\end{array}$ & - & - \\
\hline $\mathrm{H} 8$ & $\begin{array}{l}\text { B. spinosum } \\
(65 \%)\end{array}$ & $\begin{array}{c}\text { Rosaceae } \\
(23 \%)\end{array}$ & Brassicaceae (8\%) & $\begin{array}{c}\text { Oleaceae, Rhamnaceae, Asteraceae, Lamiaceae, } \\
\text { Plantaginaceae, Cistaceae, Rosaceae }\end{array}$ \\
\hline
\end{tabular}

especially due to the glucose oxidase activity that bees add during ripening [25]. These $\mathrm{pH}$ variations depend on many factors, in particular, geographic origin and climatic conditions [26]. The difference in $\mathrm{pH}$ values can also be due to the presence of nectar from other floral sources in our samples [27]. Thus, $\mathrm{pH}$ could be considered as an essential marker of the honey's geographic origin.

The content of lactone in honey samples was between $5.51 \mathrm{mEq} / \mathrm{kg}$ (obtained in the sample harvested in 2015) and $14.14 \mathrm{mEq} / \mathrm{kg}$ (obtained in the sample harvested in 2016). These results are lower than those obtained by Elamine et al. for twelve samples of $B$. spinosum honey produced in other regions of Morocco $(14.00 \mathrm{mEq} / \mathrm{kg}$ and $18.50 \mathrm{mEq} / \mathrm{kg})$ [28]. The wide variation of lactonic acidity in honey is mainly attributed to the harvest year and botanical source of secondary nectar [29].

Free acidity values of all honeys were between $12.16 \mathrm{mEq} / \mathrm{kg}$ and $31.85 \mathrm{mEq} / \mathrm{kg}$, and these results were within the permitted range and below the limits fixed by the Codex Alimentarius $(<50 \mathrm{mEq} / \mathrm{kg})$ [22]. The total acidity values analyzed in different samples of honey ranged from $18.37 \pm 0.67 \mathrm{mEq} / \mathrm{kg}$ to $45.53 \pm 0.63 \mathrm{mEq} / \mathrm{kg}$, which indicate the absence of undesirable fermentations.

Concerning moisture, honey standards of the Codex Alimentarius [22] and EU Council [30] set the maximum value of this parameter at $20 \%$. Moisture content is a crucial parameter related to the maturity degree of honey [31]. The moisture is associated with the fermentation phenomenon and is important for the conservation of honey and hence its shelf life. In our study, B. spinosum honey samples had a moisture content ranging from $15.81 \%$ to $19.60 \%$.

Our results indicate that the ash content in all honey samples was less than $0.6 \%$. The ash content ranged between $0.21 \%$ and $0.55 \%$, with the highest value detected in honey from Enjil. These significant differences reaffirm the importance of soil type, geographical diversity, and edafoclimatic characteristics from where the butined flowers are located [32], which agrees with data reported by El-Haskoury et al. [33] for monofloral carob honey from different Moroccan regions that showed a strong variation in ash content, ranging between $0.13 \%$ and $0.69 \%$. Our results are in accordance with the recommendations of the European Unit Council [30].

The Electrical conductivity is the ability of a body to allow the passage of electrical current. It depends on the mineral content and acidity of the honey [34]. It is the most useful quality parameter for the classification of monofloral honeys [9]. The electrical conductivity values of our honey samples vary between 427.38 and $682.16 \mu \mathrm{S} / \mathrm{cm}$, with the lower value referred to the Ribat El-Kheire honey sample and the higher value corresponding to honey sample from the Enjil station. These values are below the maximum value of $800 \mu \mathrm{S} / \mathrm{cm}$ as specified in Codex Alimentarius and EU Council $[22,30]$.

Diastase activity is one of the major indicators of conditioning and storage of honey, and it is used for confirmation of honey freshness [35]. In this study, all honey samples had a higher diastatic activity than the minimum required by the EU Council (8.0 shading units/g) [30]. Nevertheless, it should be noted that a large variability was found among the samples from 10.76 to 22.98 (units of shade/g).

Honey color is an essential indicator that reflects the presence of some components, for instance, terpenes, polyphenols, and carotenoids [10]. In our honey samples, the observed colors ranged from extra white (30,47 mm Pfund) in honey from Ribat El-Kheire to dark amber $(175,53 \mathrm{~mm}$ Pfund) in honey from Enjil, explaining the variability seen 


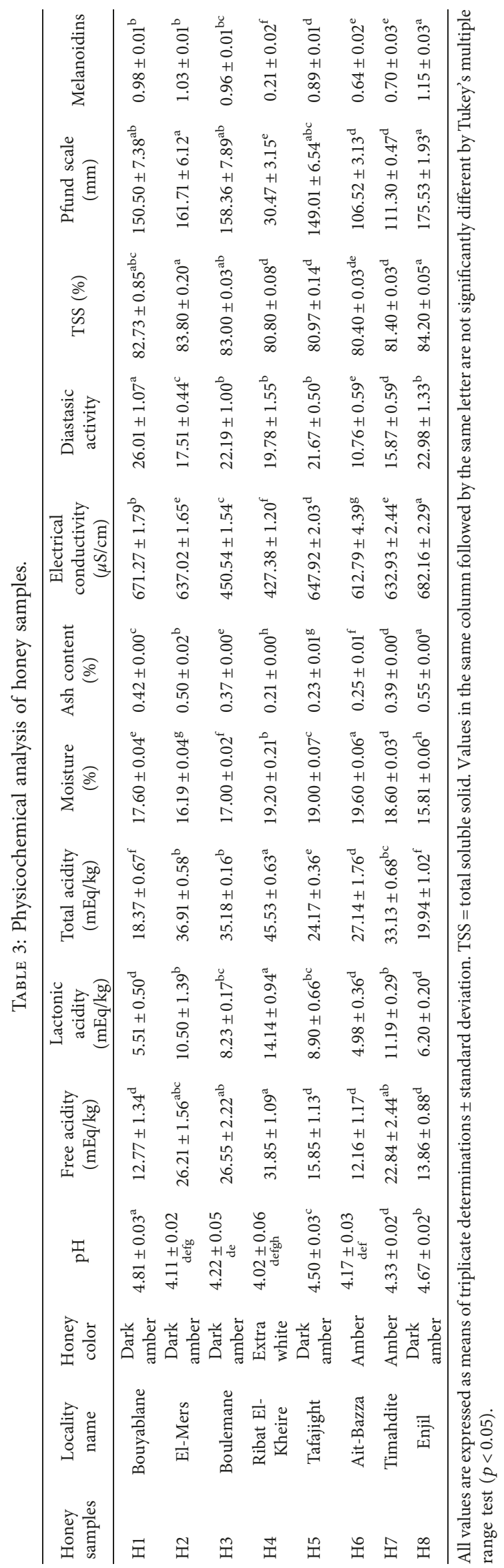


amongst the analyzed samples. Melanoidins or Maillard reaction products have been estimated as the difference between the two wavelengths (A560-A720), and they are formed when sugars and amino acids combine [11]. These results go in hand with the range of color standard designation sited by the United States Standards for Grades of Extracted Honey (USDA) [36].

The values of TSS varies between 80.40 and $84.20 \%$, the sample of Enjil presents the highest value of dry matter (84.2\%), while the sample of Ait bazza presents the lowest value $(80.4 \%)$, and TSS is inversely proportional to the moisture. According to the United States Standards for Grades of Extracted Honey (USDA), if the value of TSS was more than $80 \%$, honey can be considered of high grade and highly stable during storage [36].

3.3. Determination of Mineral Elements. The mineral content of the honeys studied is indicated in Table 4. In general, the most representative minerals are potassium, sodium, and calcium, which is in agreement with the study of Aazza et al. [37]. The trace minerals present in our honey samples ranged between $0.75 \pm 0.08 \mathrm{mg} / \mathrm{kg}$ and $3.07 \pm 0.27 \mathrm{mg} / \mathrm{kg}$ for iron $(\mathrm{Fe})$, between $1.09 \pm 0.07 \mathrm{mg} / \mathrm{kg}$ and $4.02 \pm 0.19 \mathrm{mg} / \mathrm{kg}$ for zinc ( $\mathrm{Zn}$ ), between $0.14 \pm 0.04 \mathrm{mg} / \mathrm{kg}$ and $1.53 \pm 0.04 \mathrm{mg} /$ $\mathrm{kg}$ for copper $(\mathrm{Cu})$, and between $0.03 \pm 0.01 \mathrm{mg} / \mathrm{kg}$ and $0.13 \pm 0.009 \mathrm{mg} / \mathrm{kg}$ for Nickel (Ni), and the determination of the mineral content in honey is a useful tool to determine the botanical origin [38]. There is no specific legislation on maximum limits for mineral content in honey, and it is not yet considered as a quality parameter of Codex Alimentarius Commission Standards [22].

These trace elements play different functions within our organism such as second messengers and catalysis of various biochemical reactions [39]. However, heavy metals ( $\mathrm{Pb}$ and $\mathrm{Cd}$ ) were not detected in all samples analyzed except $\mathrm{H} 4$ from the area of Ribat El-Kheire which showed a low concentration of Cd $0.02 \mathrm{mg} / \mathrm{kg}$, which is included in the range acceptable of EU Legislation $(0.05 \mathrm{mg} / \mathrm{Kg})$ [40]. These results confirm the purity and the quality of our honey samples.

3.4. Bioactive Compounds and Antioxidant Activities. The results of the antioxidant activity are shown in the Table 5 . The dosage of TAA, Phenols, flavonoids, DPPH, and ascorbic acid are important criteria for the evaluation of the nutritional and therapeutic quality of honey [41]. The phenol content of our analyzed samples varies between $85.03 \pm 5.78 \mathrm{mg} \mathrm{GAE} / 100 \mathrm{~g}$ and $229.54 \pm 7.71 \mathrm{mg} \mathrm{GAE} / 100 \mathrm{~g}$ from Ribat El-Kheire and Enjil, respectively. These results are higher than those reported by Bouhlali et al. for Moroccan monofloral honeys of carob, Eucalyptus, Harmal, Jujube, Lavender, Orange, Rosemary, and Roseda [42] and by Petretto et al. for Moroccan monofloral honeys of Asparagus, Citrus, Carob, Euphorbe, Eucalyptus, Orange, and Thyme [43].

In addition to phenols, honey contains other compounds that have a very important antioxidant role such as ascorbic acid. In our samples, the concentration of ascorbic acid varies between $4.53 \pm 0.12 \mathrm{mg} / 100 \mathrm{~g}$ and $18.27 \pm 0.74 \mathrm{mg} /$ $100 \mathrm{~g}$. The lowest value corresponds to the station of AitBazza, while the highest value corresponds to the station of El-Mers, which is similar to those reported for monofloral Portuguese honeys of Rosmarinus officinalis, Echium vulgare, and Erica australis [44] and monofloral Burkina Fasan honeys of Acacia and Lannea [45].

Flavonoids are low-molecular-weight substances which have a large contribution to the antioxidant activity of honey in addition to their aromatic roles [46]. In this study, the flavonoid content ranged from $04.38 \pm 0.30 \mathrm{mg} \mathrm{QE} / 100 \mathrm{~g}$ to $12.9 \pm 0.82 \mathrm{mg} \mathrm{QE} / 100 \mathrm{~g}$ and the honey samples from the area of Ait-Bazza had the lowest concentration, while the area of Enjil had the higher concentration. The results obtained are similar to those obtained by Bouhlali et al. in Moroccan monofloral honeys of Carob, Eucalyptus, Harmal, Jujube, Lavender, Orange, Rosemary, and Spurge [42].

The total antioxidant activity of analyzed samples varied from $75.27 \pm 3.87 \mathrm{AAE} / \mathrm{g}$ to $129.30 \pm 9.85 \mathrm{mg}$. AAE $/ \mathrm{g}$, which is higher than that signaled for Moroccan carob honeys [33].

Regarding free radical scavenging ability (DPPH) of honey samples, the concentration of honey required to inhibit $50 \%$ of DPPH varied between $13.54 \pm 0.51 \mathrm{mg} / \mathrm{mL}$ and $45.34 \pm 0.45 \mathrm{mg} / \mathrm{mL}$. The sample of provenance of ElMers has the highest percentage of inhibition, while the sample of area of Tafajight has the lowest percentage of inhibition. The high radical scavenging activity could be due to its richness of ascorbic acid, phenols, and flavonoids [47].

There is a strong relationship between the pollen profile of honey and its content in antioxidant compounds [48]. In our study, we found that honey samples of similar floral origin B. spinosum collected from different localities showed a variation in phenols, flavonoids, ascorbic acid, TAA, and DPPH. The same results were found by Aazza et al. for monofloral honeys of Thyme and Jujube [37]. The most likely explanation of these results is the presence of pollen that belongs to secondary floral sources, and that intervenes in the antioxidant activity of honey.

3.5. Microbiological Quality. Despite the high concentration of bioactive compounds in honey, some microorganisms can withstand acidity, high concentration of sugars, and antimicrobial molecules and can survive and grow in honey, which poses a real threat to consumers, especially, immunodepressed people, children, and the elderly.

As shown in the Table 6, aerobic mesophilic bacteria were present in all honey samples, except in sample $\mathrm{H} 1$ (Bouyablane) and ranged from (0 to $45 \mathrm{CFU} / \mathrm{g}$ ), which is in accordance with the French standards (levels of aerobic mesophilic bacteria below $1000 \mathrm{CFU} / \mathrm{g}$ ) [49]. These results are generally lower than that obtained in Moroccan monofloral honeys of Thymus broussonetti, and Euphorbia resinifera [25]. The low values of aerobic mesophilic bacteria in our analyzed samples provide information on good beekeeping practices and honey conditioning storage.

Faecal coliforms are indicators of faecal contamination and poor hygienic conditions, and all samples were negative for faecal coliforms count, which suggests the respect of the 


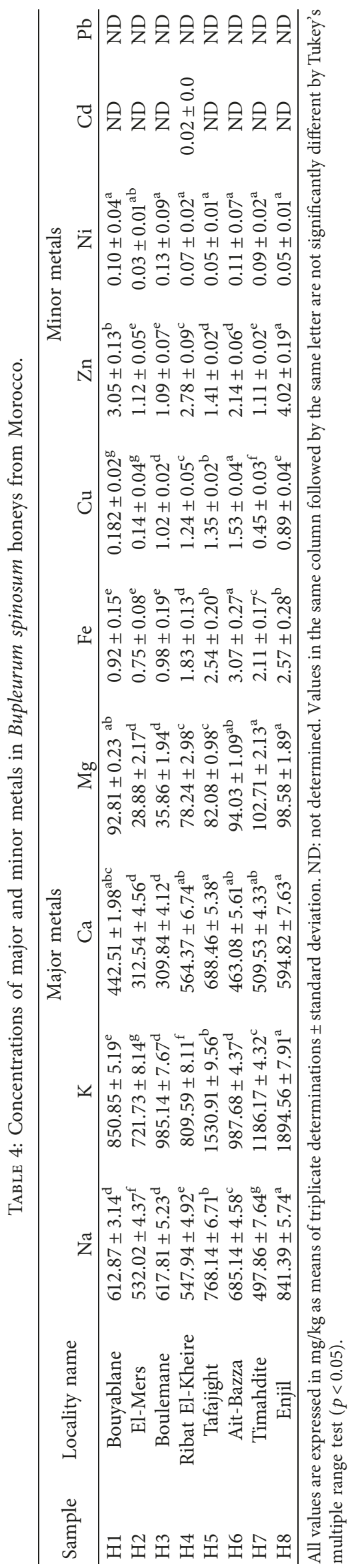


TABLE 5: Bioactive compounds and antioxidant activities.

\begin{tabular}{lcccccc}
\hline Sample & Locality name & $\begin{array}{c}\text { Phenols } \\
(\mathrm{mg} \cdot \mathrm{GAE} / 100 \mathrm{~g})\end{array}$ & $\begin{array}{c}\text { Flavonoids } \\
(\mathrm{mg} \cdot \mathrm{QE} / 100 \mathrm{~g})\end{array}$ & TAA (mg.AAE/g) & DPPH $\left(\mathrm{IC} \mathrm{F}_{50}=\mathrm{mg} / \mathrm{mL}\right)$ & Ascorbic acid (mg/100 g) \\
\hline H1 & Bouyablane & $158.94 \pm 8.12^{\mathrm{b}}$ & $10.28 \pm 0.52^{\mathrm{b}}$ & $105.56 \pm 7.35^{\mathrm{a}}$ & $17.51 \pm 0.82^{\mathrm{d}}$ & $10.76 \pm 1.12^{\mathrm{bc}}$ \\
H2 & El-Mers & $212.34 \pm 11.25^{\mathrm{a}}$ & $12.03 \pm 0.58^{\mathrm{a}}$ & $129.30 \pm 9.85^{\mathrm{a}}$ & $13.54 \pm 0.51^{\mathrm{e}}$ & $18.27 \pm 0.74^{\mathrm{a}}$ \\
H3 & Boulemane & $152.36 \pm 6.34^{\mathrm{c}}$ & $7.56 \pm 0.22^{\mathrm{c}}$ & $118.94 \pm 8.18^{\mathrm{a}}$ & $22.58 \pm 0.94^{\mathrm{c}}$ & $14.08 \pm 2.39^{\mathrm{b}}$ \\
H4 & Ribat El-Kheire & $85.03 \pm 5.78^{\mathrm{de}}$ & $5.71 \pm 0.34^{\mathrm{d}}$ & $75.27 \pm 3.87^{\mathrm{a}}$ & $37.06 \pm 0.27^{\mathrm{b}}$ & $9.15 \pm 1.58^{\mathrm{d}}$ \\
H5 & Tafajight & $110.13 \pm 4.13^{\mathrm{d}}$ & $7.64 \pm 0.28^{\mathrm{c}}$ & $96.87 \pm 7.15^{\mathrm{a}}$ & $45.34 \pm 0.45^{\mathrm{a}}$ & $7.35 \pm 0.55^{\mathrm{e}}$ \\
H6 & Ait-Bazza & $86.15 \pm 2.85^{\mathrm{de}}$ & $4.38 \pm 0.30^{\mathrm{d}}$ & $82.27 \pm 2.37^{\mathrm{a}}$ & $35.14 \pm 0.43^{\mathrm{b}}$ & $4.53 \pm 0.12^{\mathrm{e}}$ \\
H7 & Timahdite & $92.88 \pm 9.75^{\mathrm{de}}$ & $5.11 \pm 0.49^{\mathrm{d}}$ & $75.80 \pm 3.66^{\mathrm{a}}$ & $35.68 \pm 0.67^{\mathrm{b}}$ & $5.87 \pm 0.48^{\mathrm{e}}$ \\
H8 & Enjil & $229.54 \pm 7.71^{\mathrm{a}}$ & $12.9 \pm 0.82^{\mathrm{a}}$ & $124.82 \pm 7.48^{\mathrm{a}}$ & $13.89 \pm 0.58^{\mathrm{e}}$ & $12.38 \pm 0.73^{\mathrm{b}}$ \\
\hline
\end{tabular}

Values in the same column followed by the same letter are not significantly different by Tukey's multiple range test $(p<0.05)$.

TABle 6: Microbiological quality.

\begin{tabular}{|c|c|c|c|c|c|c|c|}
\hline Sample & $\begin{array}{l}\text { Locality } \\
\text { name }\end{array}$ & $\begin{array}{l}\text { Aerobic mesophilic } \\
\text { bacteria }(\mathrm{CFU} \cdot \mathrm{g}-1)\end{array}$ & $\begin{array}{l}\text { Fecal coliforms } \\
\text { (MPN) }\end{array}$ & $\begin{array}{l}\text { Moulds and } \\
\text { yeast } \\
(\mathrm{CFU} \cdot g-1)\end{array}$ & $\begin{array}{l}\text { Sulphite-reducing } \\
\text { clostridia (in } 0.01 \mathrm{~g} \text { ) }\end{array}$ & $\begin{array}{l}\text { Salmonella spp. } \\
\quad \text { (in } 25 \mathrm{~g})\end{array}$ & $\begin{array}{c}\text { Bacillus } \\
\text { sp. }\end{array}$ \\
\hline $\mathrm{H} 1$ & Bouyablane & Negative & $<1$ & 10 & Negative & Negative & $<10$ \\
\hline $\mathrm{H} 2$ & El-Mers & 20 & $<1$ & 29 & Negative & Negative & $<10$ \\
\hline $\mathrm{H} 3$ & Boulemane & 45 & $<1$ & 24 & Negative & Negative & $<10$ \\
\hline $\mathrm{H} 4$ & $\begin{array}{l}\text { Ribat El- } \\
\text { Kheire }\end{array}$ & 20 & $<1$ & 52 & Negative & Negative & $<10$ \\
\hline H5 & Tafajight & 10 & $<1$ & 19 & Negative & Negative & $<10$ \\
\hline H6 & Ait-Bazza & 18 & $<1$ & 17 & Negative & Negative & $<10$ \\
\hline $\mathrm{H} 7$ & Timahdite & 20 & $<1$ & 37 & Negative & Negative & $<10$ \\
\hline $\mathrm{H} 8$ & Enjil & 20 & $<1$ & 12 & Negative & Negative & $<10$ \\
\hline
\end{tabular}

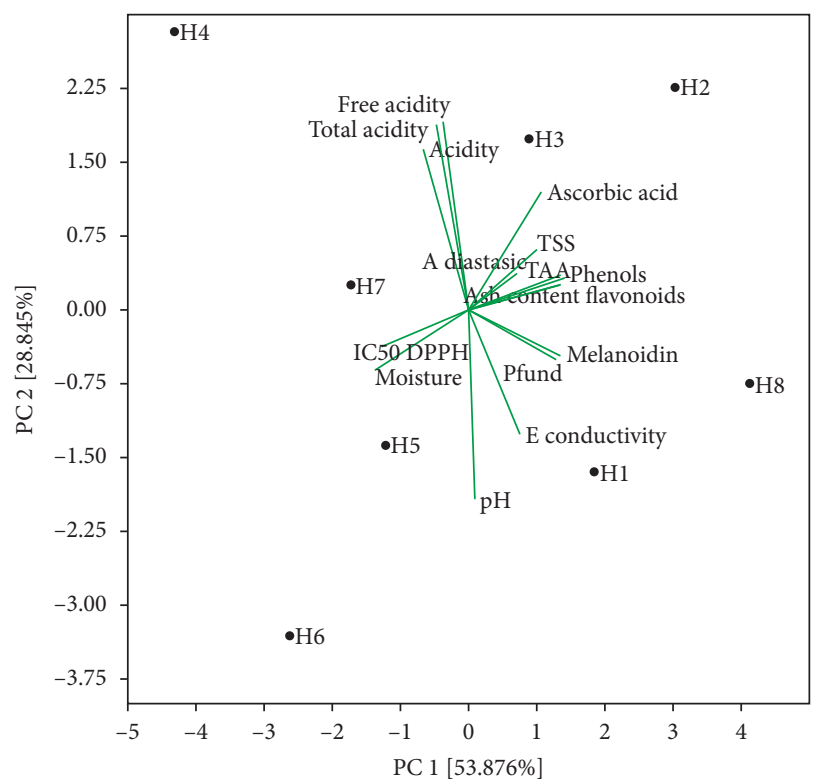

(a)

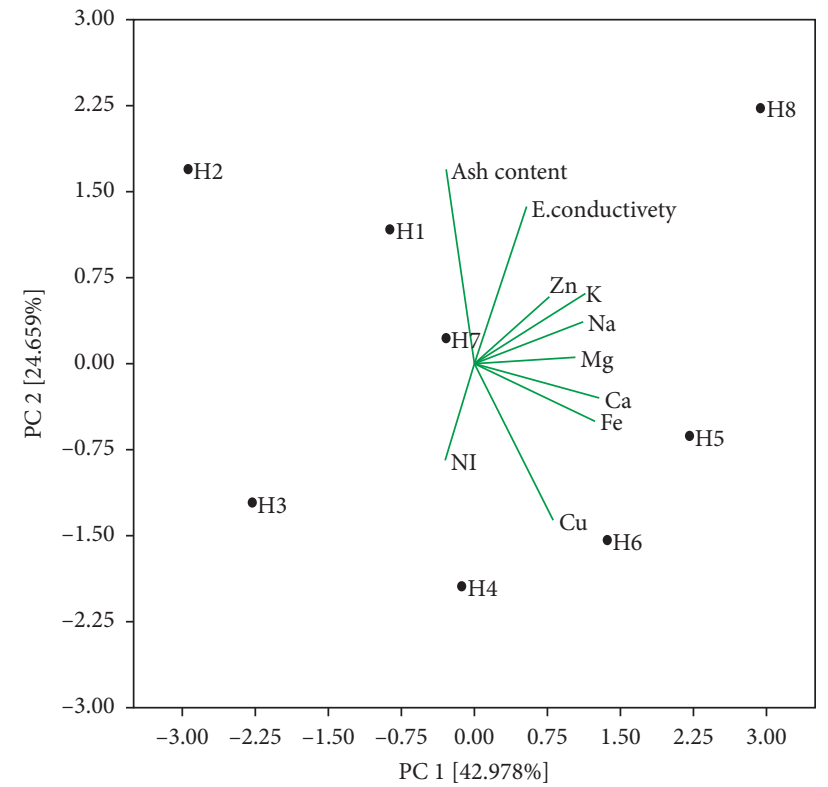

(b)

FIGURE 2: Principal component analysis: (a) biplots of honey samples using physicochemical parameters and the antioxidant activities. (b) Biplots of honey samples using electrical conductivity, ash, and mineral content.

good practices of harvest and conditioning of the honey, which agrees with data found by Kunová et al. [7] and Iglesias et al. [50].
Regarding safety, none of the eight honey samples contained sulphite-reducing clostridia, and Salmonella spp. could be attributed to the antibacterial molecules, $\mathrm{pH}$ acid, 
and low water activity, which is an unfavorable environment for the development of these bacteria. Our results corroborate with the findings of Moujanni et al. illustrate a negative result regarding Salmonella spp. in thirty-seven samples of labeled honey collected from the Tadla-Azilal region of Morocco [51].

Regarding moulds and yeasts analysis, our results showed values ranged from 10 to $52 \mathrm{CFU} / \mathrm{g}$. The sample of provenance of Ribat El-Kheire has the highest value, while the samples of area of Bouyablane had the lower. These results are lower than those reported previously by Feás et al. in artisanal honeys from the Northeast of Portugal. These results are most probably attributed to the environmental conditions, good practice of beekeepers, and good management of hives [52]. However, Bacillus sp. was ${ }^{\wedge} 10$ in all samples, which is lower than that obtained in monofloral (Eucalyptus globulus and Euphorbia resinifera) and multifloral Moroccan honey [25].

3.6. Correlations and Multivariate Analysis. Honey samples distribution and homogeneity founded on their physicochemical and biochemical parameters were studied using principal component analysis. The outcomes were mentioned in Figure 2. For Figure 2(a), the first component explained $(53.876 \%)$ and represented in its positive part: ascorbic acid, TSS, diastasic acidity, flavonoids, phenols, Pfund, and Melanoidins, while the $\mathrm{IC}_{50} \mathrm{DPPH}$ and Moisture were the dominating parameters in the negative part. The second principal component explained $(28.845 \%)$ of the given results and represented mainly the free acidity, total acidity, and acidity in the positive part and the $\mathrm{pH}$ and electrical conductivity in the negative part.

The $\mathrm{H} 2$ and $\mathrm{H} 8$ honey samples shared the features regarding the bioactive compounds (phenols, flavonoids, and ascorbic acid), ash content, total antioxidant activity, and TSS. These features are already documented by other workers [37]. The variability of bioactive compounds and mineral elements may be specific to botanical origins.

The results of the geographical component of the honey samples have been shown in Figure 2(b). The given data (mineral elements, electrical conductivity, and ash content) were highly conserved in the first component which explained $42.978 \%$ and represented in its positive part: electrical conductivity, $\mathrm{Zn}, \mathrm{K}, \mathrm{Na}, \mathrm{Mg}$, $\mathrm{Ca}$, and $\mathrm{Fe}$. The second component explained $24.659 \%$ of the given data and represented ash content and electrical conductivity in the positive part and $\mathrm{Ni}$ and $\mathrm{Cu}$ in the negative part. Consequently, the first component correlated positively the electrical conductivity and $\mathrm{Zn}, \mathrm{K}, \mathrm{Na}, \mathrm{Mg}$, Ca, and Fe. H5 and $\mathrm{H} 8$ were characterized by high $\mathrm{K}, \mathrm{Na}$, and $\mathrm{Ca}$ content and electrical conductivity. The increase in potassium content in honey samples could be attributed to the botanical origin [37]. The mineral content of honey samples was a potential indicator of its geographical origin, as well as a biomarker of pollution by toxic metals [53]. In this study, the quantitative variability of minerals could be attributed to the soil composition and climatic conditions of each harvesting station. The principal component analysis in the study conducted by
Elamine et al. on twelve samples of B. Spinosum honey showed that some samples are similar, even though originated from different geographical regions [28], whereas in the present study, honey samples of the same floral origin showed a difference in the parameters studied.

\section{Conclusion}

Overall, we can conclude that the analyzed honey samples showed variability in their antioxidant contents and physicochemical parameters and the changes in the parameters analyzed seem to be due to the geographical differences, weather, soil composition, or additional floral plant sources. The physicochemical properties and microbiological status of the honeys indicate that the eight samples are in accordance with the international norms, which indicates the good beekeeping practices used by beekeepers during honey harvesting.

The present finding provides new constructive information to apply in the process of honey standardization in Morocco.

\section{Data Availability}

The data used to support the findings of this study are included within the article.

\section{Conflicts of Interest}

The authors declare that they have no conflicts of interest.

\section{Acknowledgments}

This work was supported by a grant from University Sidi Mohamed Ben Abdallah for Laboratory Physiology-Pharmacology \& Environmental Health.

\section{References}

[1] C. Viel and J.-C. Doré, "Histoire et emplois du miel, de l'hydromel et des produits de la ruche," Revue d'histoire de la pharmacie, vol. 91, no. 337, pp. 7-20, 2003.

[2] A. Belay, W. K. Solomon, G. Bultossa, N. Adgaba, and S. Melaku, "Physicochemical properties of the Harenna forest honey, Bale, Ethiopia," Food Chemistry, vol. 141, no. 4, pp. 3386-3392, 2013.

[3] S. Saxena, S. Gautam, and A. Sharma, "Physical, biochemical and antioxidant properties of some Indian honeys," Food Chemistry, vol. 118, no. 2, pp. 391-397, 2010.

[4] G. A. Nayik and V. Nanda, "A chemometric approach to evaluate the phenolic compounds, antioxidant activity and mineral content of different unifloral honey types from Kashmir, India," LWT, vol. 74, pp. 504-513, 2016.

[5] S. Ayoub, S. A. Al-asiri, and A. Latief, "Role of honey in modern medicine," Saudi Journal of Biological Sciences, vol. 24, no. 5, pp. 975-978, 2017.

[6] A. Moujanni, A. K. Essamadi, and A. Terrab, "Beekeeping in Morocco: focus on honey production," International Journal of Innovation and Applied Studies, vol. 20, no. 1, pp. 52-78, 2017.

[7] S. Kunová, M. Kačániová, P. Haščík, and J. Čuboň, "Microbiological and chemical quality of Slovak and European 
honey," Journal of Microbiology, Biotechnology and Food Sciences, vol. 4, no. 1, pp. 41-44, 2015.

[8] J. Louveaux, A. Maurizio, and G. Vorwohl, "Methods of melissopalynology," Bee World, vol. 59, no. 4, pp. 139-157, 1978.

[9] S. Bogdanov, "Harmonised methods of the honey commission," International Honey Commission, no. 5, pp. 1-62, 2002.

[10] O. A. Naab, M. A. Tamame, and M. A. Caccavari, "Palynological and physicochemical characteristics of three unifloral honey types from central Argentina," Spanish Journal of Agricultural Research, vol. 6, no. 4, pp. 566-576, 2008.

[11] K. Brudzynski and D. Miotto, "Honey melanoidins: analysis of the compositions of the high molecular weight melanoidins exhibiting radical-scavenging activity," Food Chemistry, vol. 127, no. 3, pp. 1023-1030, 2011.

[12] L. R. Silva, R. Videira, A. P. Monteiro, P. Valentão, and P. B. Andrade, "Honey from Luso region (Portugal): physicochemical characteristics and mineral contents," Microchemical Journal, vol. 93, no. 1, pp. 73-77, 2009.

[13] M. Bakour, N. Soulo, N. Hammas et al., "The antioxidant content and protective effect of argan oil and syzygium aromaticum essential oil in hydrogen peroxide-induced biochemical and histological changes," International Journal of Molecular Sciences, vol. 19, no. 2, p. 610, 2018.

[14] C. C. Nweze, M. G. Abdulganiyu, and O. G. Erhabor, "Comparative analysis of vitamin $\mathrm{C}$ in fresh fruits juice of Malus domestica, Citrus sinensi, Ananas comosus and Citrullus lanatus by iodometric titration," International Journal of Environmental Science and Technology, vol. 4, no. 1, pp. 17-22, 2015.

[15] M. D. G. Miguel, O. Doughmi, S. Aazza, D. Antunes, and B. Lyoussi, "Antioxidant, anti-inflammatory and acetylcholinesterase inhibitory activities of propolis from different regions of Morocco," Food Science and Biotechnology, vol. 23, no. 1, pp. 313-322, 2014.

[16] NP-3788, Microbiologia Alimentar-Regras Gerais Para a Contagem de Microrganismos a $30^{\circ} \mathrm{C}$, Instituto Português da Qualidade, Lisbon, Portugal, 2002.

[17] ISO 21527-2, Microbiology of Food and Animal Feeding Stuffs-Horizontal Method for the Enumeration of Yeasts and Moulds-Part 2: Colony Count Technique in Products with Water Activity Less Than or Equal to 0.95, International Standards Organization, Geneva, Switzerland, 2008.

[18] ISO 4831, Microbiology of Food and Animal Feeding Stuffs-Horizontal Method for the Detection and Enumeration of Coliforms-Most Probable Number Technique, International Standards Organization, Geneva, Switzerland, 2006.

[19] ISO 6579:2002(E), Microbiology of Food and Animal Feeding Stuffs-Horizontal Method for the Detection of Salmonella Spp, International Standards Organization, Geneva, Switzerland, 2002.

[20] N. F. Lightfoot and E. A. Maier, Análisis microbiológico de alimentos y aguas, Directrices Para El Asegur Calid, Editorial Acribia S. A., Zaragoza, Spain, 2002.

[21] B. Herrero, R. María Valencia-Barrera, R. San Martín, and V. Pando, "Characterization of honeys by melissopalynology and statistical analysis," Canadian Journal of Plant Science, vol. 82, no. 1, pp. 75-82, 2002.

[22] Codex Alimentarius Commission, Revised Codex Standard for Honey, Codex Alimentarius Commission, Rome, Italy, Codex STAN, 12-1981, 2001.

[23] T. Ruiz-argueso and A. Rodriguez-Navarro, "Gluconic acidproducing bacteria from honey bees and ripening honey," Journal of General Microbiology, vol. 76, no. 1, pp. 211-216, 1973.
[24] I. Mato, J. F. Huidobro, J. Simal-Lozano, and M. T. Sancho, "Significance of nonaromatic organic acids in honey," Journal of Food Protection, vol. 66, no. 12, pp. 2371-2376, 2003.

[25] N. Malika, F. Mohamed, and E. A. Chakib, "Microbiological and physicochemical properties of Moroccan honey," International Journal of Agriculture and Biology, vol. 7, no. 5, pp. 773-776, 2005.

[26] C. Acquarone, P. Buera, and B. Elizalde, "Pattern of $\mathrm{pH}$ and electrical conductivity upon honey dilution as a complementary tool for discriminating geographical origin of honeys," Food Chemistry, vol. 101, no. 2, pp. 695-703, 2007.

[27] K. B. Lazarević, F. Andrić, J. Trifković, Ž. Tešić, and D. Milojković-Opsenica, "Characterisation of Serbian unifloral honeys according to their physicochemical parameters," Food Chemistry, vol. 132, no. 4, pp. 2060-2064, June 2012.

[28] Y. Elamine, S. Aazza, B. Lyoussi et al., "Preliminary characterization of a Moroccan honey with a predominance of Bupleurum spinosum pollen," Journal of Apicultural Research, vol. 57, no. 1, pp. 153-165, 2017.

[29] S. Ajlouni and P. Sujirapinyokul, "Hydroxymethylfurfuraldehyde and amylase contents in Australian honey," Food Chemistry, vol. 119, no. 3, pp. 1000-1005, 2010.

[30] EU Council, "Council directive 2001/11 O/EC of 20 december 2001 relating to honey," Official Journal of the European Communities, vol. L10, pp. 47-52, 2002.

[31] A. Chakir, A. Romane, G. L. Marcazzan, and P. Ferrazzi, "Physicochemical properties of some honeys produced from different plants in Morocco," Arabian Journal of Chemistry, vol. 9, pp. S946-S954, 2016.

[32] O. Escuredo, M. Miguez, M. Fernandez-Gonzalez, and M. Carmen Seijo, "Nutritional value and antioxidant activity of honeys produced in a European Atlantic area," Food Chemistry, vol. 138, no. 2-3, pp. 851-856, juin 2013.

[33] R. El-Haskoury, W. Kriaa, B. Lyoussi, and M. Makni, "Ceratonia siliqua honeys from Morocco: physicochemical properties, mineral contents, and antioxidant activities," Journal of Food and Drug Analysis, vol. 26, no. 1, pp. 67-73, 2018.

[34] S. Bogdanov, "Honey for Nutrition and Health," Book Honey, vol. 7, 2009.

[35] E. Anklam, "A review of the analytical methods to determine the geographical and botanical origin of honey," Food Chemistry, vol. 63, no. 4, pp. 549-562, 1998.

[36] USDA, United States Standards for Grades of Extracted Honey, Agricultural Marketing Service, Washington, DC, USA, 1985.

[37] S. Aazza, B. Lyoussi, D. Antunes, and M. G. Miguel, "Physicochemical characterization and antioxidant activity of 17 commercial Moroccan honeys," International Journal of Food Sciences and Nutrition, vol. 65, no. 4, pp. 449-457, 2014.

[38] P. Wetwitayaklung, B. Wangwattana, and W. Narakornwit, "Determination of trace-elements and toxic heavy minerals in Thai longan, litchi and Siam weed honeys using ICP-MS," International Food Research Journal, vol. 25, pp. 1464-1473, 2018.

[39] A. S. Alqarni, A. A. Owayss, A. A. Mahmoud, and M. A. Hannan, "Mineral content and physical properties of local and imported honeys in Saudi Arabia," Journal of Saudi Chemical Society, vol. 18, no. 5, pp. 618-625, 2014.

[40] Commission Regulation, Setting Maximum Levels for Certain Contaminants in Foodstuffs, Official Journal of the European Union, Brussels, Belgium, 2006.

[41] H. M. Habib, F. T. Al Meqbali, H. Kamal, U. D. Souka, and W. H. Ibrahim, "Physicochemical and biochemical properties of honeys from arid regions," Food Chemistry, vol. 153, pp. 35-43, 2014. 
[42] E. D. T. Bouhlali, M. Bammou, K. Sellam et al., "Evaluation of antioxidant, antibacterial and antifungal activities of eleven monofloral honey samples collected from Morocco," Journal of Chemical and Pharmaceutical Research, vol. 8, pp. 299-306, 2016.

[43] G. L. Petretto, C. I. G. Tuberoso, M. A. Fenu, J. P. Rourke, O. Belhaj, and G. Pintore, "Antioxidant activity, color chromaticity coordinates, and chemical characterization of monofloral honeys from Morocco," International Journal of Food Properties, vol. 20, no. 9, pp. 2016-2027, 2017.

[44] I. C. F. R. Ferreira, E. Aires, J. C. M. Barreira, and L. M. Estevinho, "Antioxidant activity of Portuguese honey samples: different contributions of the entire honey and phenolic extract," Food Chemistry, vol. 114, no. 4, pp. 1438-1443, 2009.

[45] A. Meda, C. E. Lamien, M. Romito, J. Millogo, and O. G. Nacoulma, "Determination of the total phenolic, flavonoid and proline contents in Burkina Fasan honey, as well as their radical scavenging activity," Food Chemistry, vol. 91, no. 3, pp. 571-577, 2005.

[46] G. Kroyer and N. Hegedus, "Evaluation of bioactive properties of pollen extracts as functional dietary food supplement," Innovative Food Science \& Emerging Technologies, vol. 2, no. 3, pp. 171-174, 2001.

[47] L. S. Chua, N. L. A. Rahaman, N. A. Adnan, and T. T. Eddie Tan, "Antioxidant activity of three honey samples in relation with their biochemical components," Journal of Analytical Methods in Chemistry, vol. 2013, Article ID 313798, 8 pages, 2013.

[48] M. Bakour, M. D. G. Campos, H. Imtara, and B. Lyoussi, "Antioxidant content and identification of phenolic/flavonoid compounds in the pollen of fourteen plants using HPLCDAD," Journal of Apicultural Research, vol. 59, no. 1, pp. 35-41, 2019.

[49] F. E. Azonwade, A. Paraïso, C. P. A. Dossa et al., "Physicochemical characteristics and microbiological quality of honey produced in Benin," Journal of Food Quality, vol. 2018, Article ID 1896057, 13 pages, 2018.

[50] A. Iglesias, X. Feás, S. Rodrigues et al., "Comprehensive study of honey with protected denomination of origin and contribution to the enhancement of legal specifications," Molecules, vol. 17, no. 7, pp. 8561-8577, 2012.

[51] A. Moujanni, A. Terrab, R. Eddoha et al., "Microbiological quality of Moroccan labeled Euphorbia resinifera honey," Journal of Microbiology, Biotechnology and Food Sciences, vol. 6, no. 5, pp. 1188-1194, 2017.

[52] X. Feás, J. Pires, A. Iglesias, and M. L. Estevinho, "Characterization of artisanal honey produced on the Northwest of Portugal by melissopalynological and physico-chemical data," Food and Chemical Toxicology, vol. 48, no. 12, pp. 3462-3470, 2010.

[53] T. M. F. F. Mendes, S. N. Baccan, and S. Cadore, "Sample treatment procedures for the determination of mineral constituents in honey by inductively coupled plasma optical emission spectrometry," Journal of the Brazilian Chemical Society, vol. 17, no. 1, pp. 168-176, 2006. 


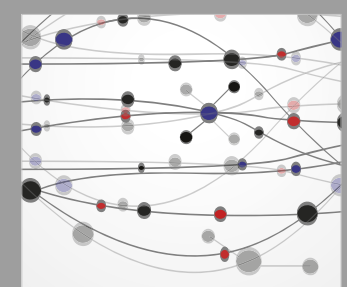

The Scientific World Journal
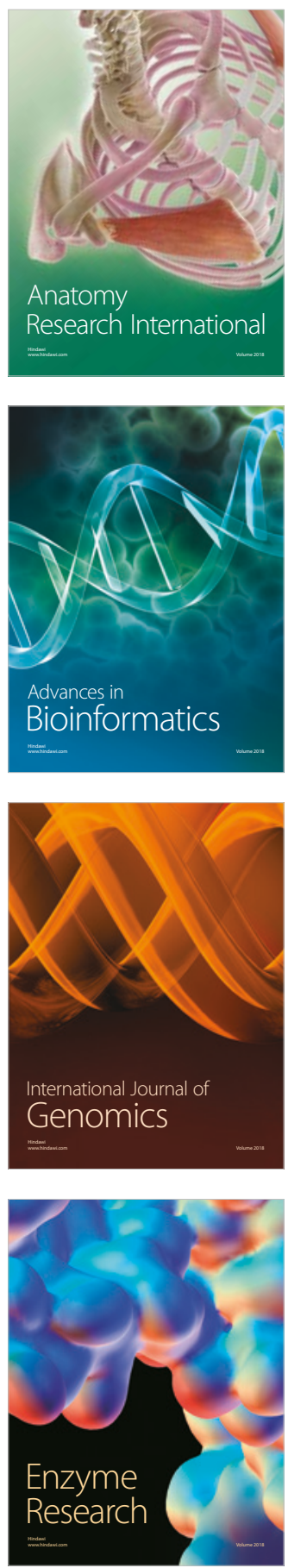
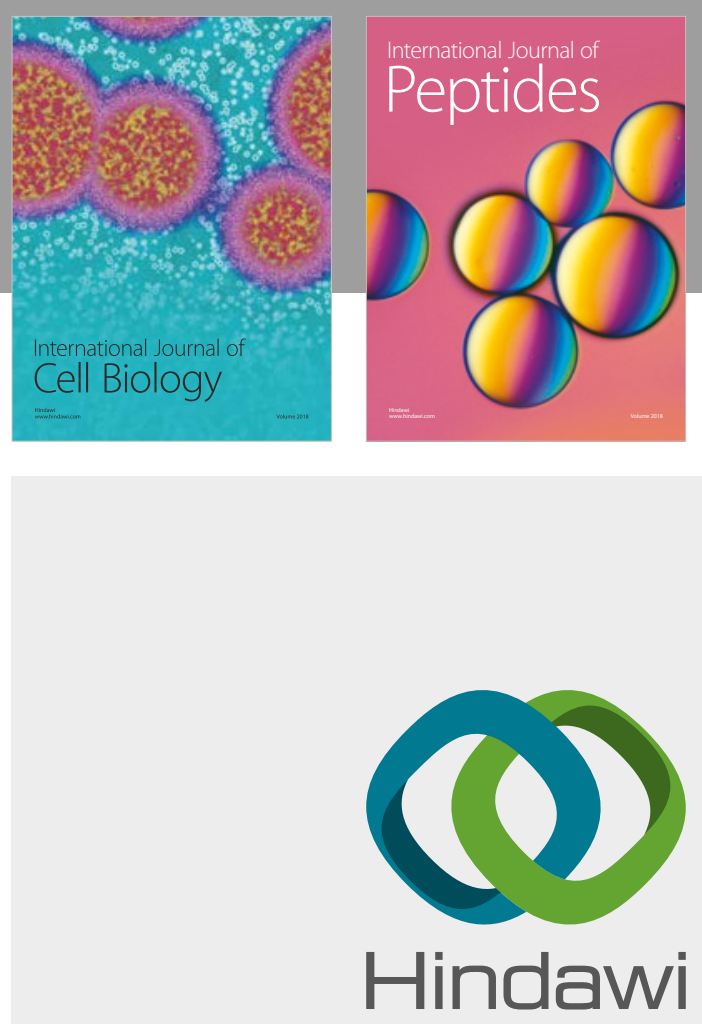

Submit your manuscripts at

www.hindawi.com
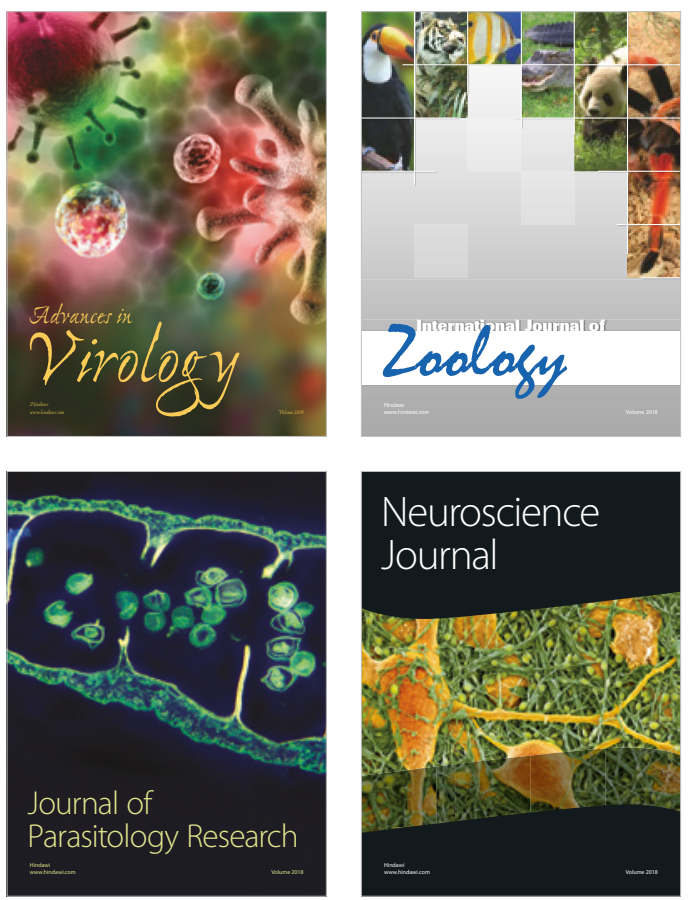
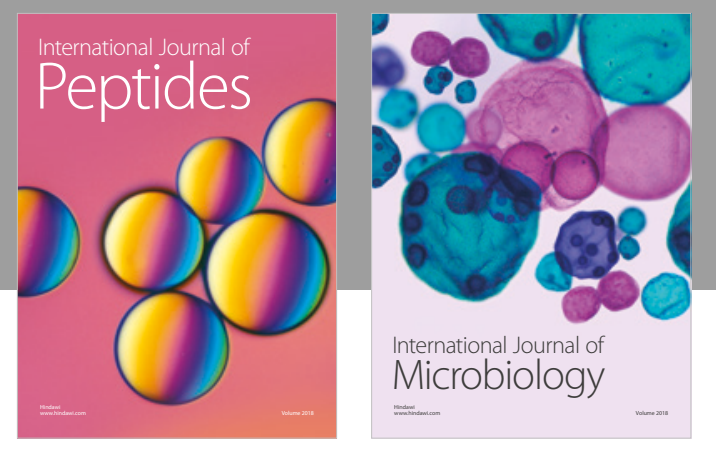

nternational Journal of Microbiology
Journal of
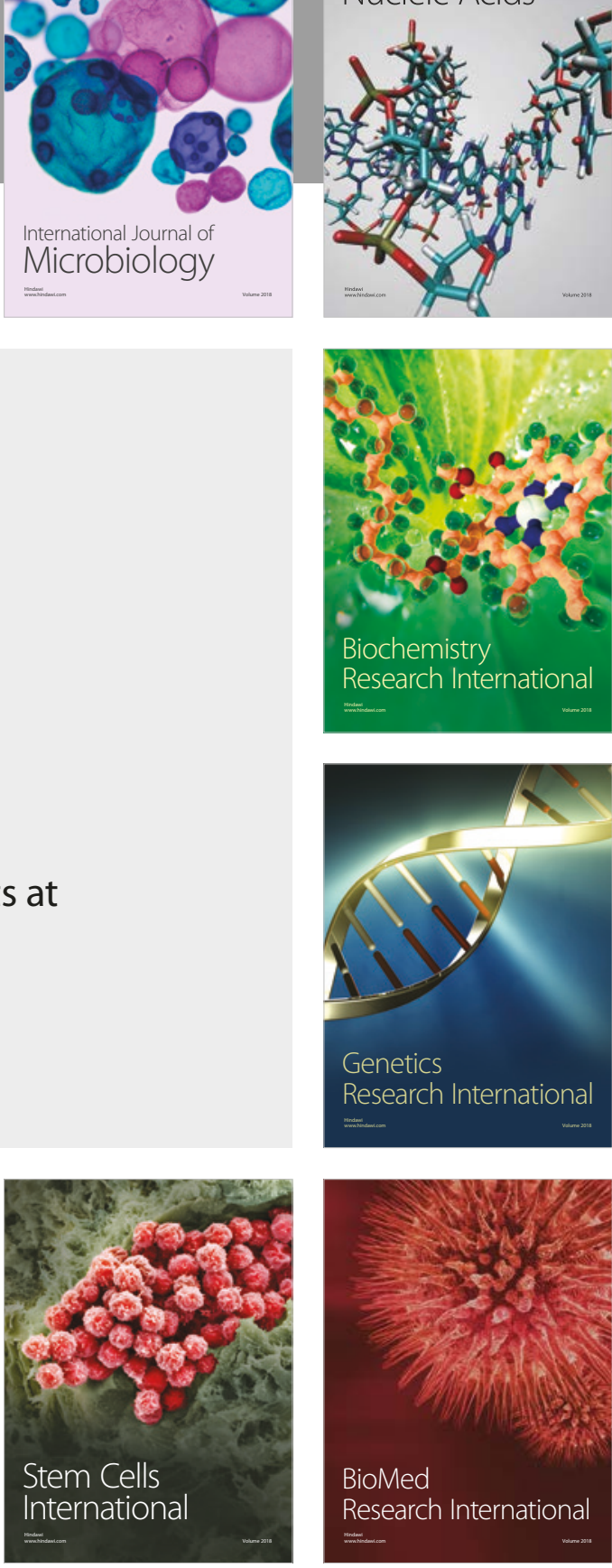
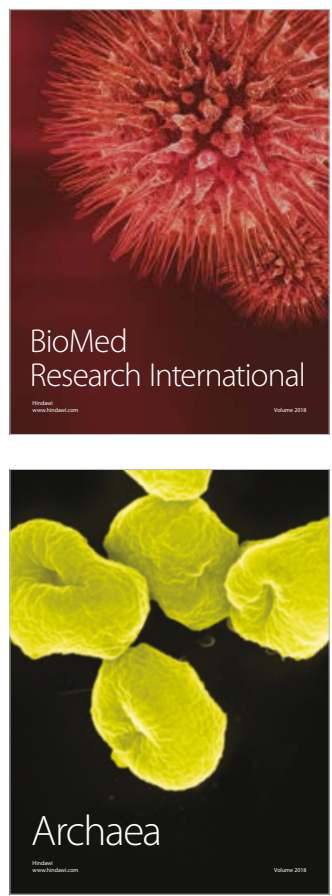